$\S=-1$

\title{
Consumer Attitudes on Domestic Water-Saving Practices in Gombak District, Selangor
}

\author{
Yendo Afgani @ Eusoff, Normadihah M. Aminuddin*, Ahmad Puad Mat Som, Aziz Amin, Norizan Abdul Ghani \\ Faculty of Applied Social Sciences, Universiti Sultan Zainal Abidin, Gong Badak Campus, 21300 Kuala Nerus, Terengganu, Malaysia \\ *Corresponding author E-mail: madihah.phd@gmail.com
}

\begin{abstract}
Consumer attitude needs to be changed to ensure the adequacy of water supply in Malaysia due to serious issues likes rising water demands, pollution, global population growth and climate change. An existing study on domestic water consumption behaviour among Malaysians are not extensively discussed in depth, whereas the constructs of consumer behaviour should be seriously addressed in the effort to create awareness on water conservation. The paper intends to identify the level of attitude of domestic water consumers according to their cognitive, conative and affective constructs. The data was collected from five territorial divisions located in Gombak, Selangor, Malaysia through survey by using structured questionnaires to 400 domestic water users from December 2016 to February 2017 . All the data were analyzed using SPSS version 21 to produce descriptive results (frequency, percentage, overall mean and standard deviation score). The findings show that the measurement level of domestic water consumers' attitudes, which were 'cognitive', 'conative' and 'affective', varied according to the determination of mean scores. Generally, the study output shows cognitive constructs are at a high level (4.71) while the conative constructs (3.27) and affective (3.15) are in moderate level. The existence of consumers' attitudes at higher levels indicate that respondents are more likely to assess the use of water carefully, to reduce the wastage of water and contribute to the reduction of monthly water bill costs among households.
\end{abstract}

Keywords: Consumer Attitude; Water-Saving; Domestic Water.

\section{Introduction}

Malaysia has the highest water consumption rate in Southeast Asia, if compared to the United Nations guidelines which suggest that the total water requirement for each person is 165 litres per day [1]. In the 1970s, Malaysians only used less than 200 litres of water a day (litres per day). The figure then increased to about 250 LPDs in the 1980s and then to more than 300 LPDs now. In urban areas, it is estimated that consumers use about 500 LPDs [2]. In watersaving studies, water users in Malaysia can be divided into two categories, domestic and non-domestic water users. This research focuses only on the behaviour of domestic water users in daily practices among the residents of Gombak District, Selangor.

\section{Literature Review}

Within ASEAN region, the rate of water usage in Malaysia is considerably high compared to other countries such as Thailand with only about 160 to 170 litres per day, Indonesia is 140 to 160 litres per day per person. Meanwhile, in Singapore, water users consume 150 litres a day [3]. Additionally, Singapore strives to reduce the number to 140 liters per day in 2030. Basically, an average of 109 to 300 litres of daily use, only 30 percent is for real consumption such as cooking and drinking, while the rest of treated water is used for utilities like watering plants, washing the pool and washing daily clothing [4].

According to the Malaysian Water Industry Guide 2016, the water consumption rate for domestic consumers for 2015 in Malaysia is on average 209 litres per day compared to the 2014 year of 211 litres. This clearly shows that lifestyle changes in domestic users have affected the amount of water use [5]. Table 1 shows the statistics of domestic water usage in Selangor was the highest compared to other states in Malaysia at 1,862 million litres per day (MLD) by 2015. Table 2 shows that domestic water consumption per capita per day in Selangor recorded a higher rate at 234 litres per capita per day by 2015 .

Table 1: Domestic and Non-Domestic Water Use for States in Malaysia in 2014

\begin{tabular}{|c|c|c|c|c|c|}
\hline \multirow{2}{*}{ State } & \multicolumn{5}{|c|}{2014} \\
\cline { 2 - 6 } & \multicolumn{2}{|c|}{ Domestic } & \multicolumn{2}{c|}{ Non-Domestic } & Amount \\
\cline { 2 - 6 } & MLD & $\%$ & MLD & $\%$ & MLD \\
\hline Johor & 823 & 67.8 & 391 & 32.2 & 1,215 \\
\hline Kedah & 510 & 73.2 & 187 & 26.8 & 697 \\
\hline Kelantan & 154 & 68.3 & 71 & 31.7 & 225 \\
\hline Labuan & 17 & 35.8 & 31 & 64.2 & 48 \\
\hline Melaka & 196 & 52.1 & 180 & 47.9 & 376 \\
\hline N. Sembilan & 259 & 54.4 & 217 & 45.6 & 476 \\
\hline Pulau Pinang & 483 & 59.4 & 330 & 40.6 & 813 \\
\hline Pahang & 303 & 58.4 & 216 & 41.6 & 520 \\
\hline Perak & 623 & 72.5 & 236 & 27.5 & 858 \\
\hline Perlis & 81 & 84.5 & 15 & 15.5 & 95 \\
\hline Sabah & 33 & 57.1 & 248 & 42.9 & 577 \\
\hline Sarawak & 469 & 57.9 & 341 & 42.1 & 810 \\
\hline Selangor* & 1,779 & 58.4 & 1,268 & 41.6 & 3,048 \\
\hline Terengganu & 241 & 57.7 & 176 & 42.3 & 417 \\
\hline Malaysia & 6,267 & 61.6 & 3,909 & 38.4 & 10,176 \\
\hline
\end{tabular}

*MLD = Million litres per day (Source: SPAN, 2017) 
Table 2: Domestic and Non-Domestic Water Use for States Malaysia in 2015

\begin{tabular}{|c|c|c|c|c|c|}
\hline \multirow{2}{*}{ State } & \multicolumn{5}{|c|}{2015} \\
\cline { 2 - 6 } & \multicolumn{2}{|c|}{ Domestic } & \multicolumn{2}{c|}{ Non-Domestic } & Amount \\
\cline { 2 - 6 } & MLD & $\%$ & MLD & $\%$ & MLD \\
\hline Johor & 811 & 64.4 & 448 & 35.6 & 1,259 \\
\hline Kedah & 511 & 72.8 & 191 & 27.2 & 702 \\
\hline Kelantan & 159 & 68.6 & 73 & 31.4 & 231 \\
\hline Labuan & 17 & 35.2 & 32 & 64.8 & 49 \\
\hline Melaka & 202 & 52.0 & 186 & 48.0 & 388 \\
\hline N. Sembilan & 276 & 55.9 & 217 & 44.1 & 493 \\
\hline Pulau Pinang & 483 & 59.5 & 329 & 40.5 & 813 \\
\hline Pahang & 309 & 58.2 & 223 & 41.8 & 532 \\
\hline Perak & 628 & 71.5 & 250 & 28.5 & 878 \\
\hline Perlis & 81 & 84.2 & 15 & 15.8 & 96 \\
\hline Sabah & 315 & 57.1 & 237 & 42.9 & 552 \\
\hline Sarawak & 478 & 56.5 & 368 & 43.5 & 846 \\
\hline Selangor* & 1,862 & 58.6 & 1,316 & 41.4 & 3,178 \\
\hline Terengganu & 246 & 57.5 & 182 & 42.5 & 428 \\
\hline Malaysia & 6,378 & 61.1 & 4,067 & 38.9 & 10,445 \\
\hline *MLD Million litres per day (Source: SPAN, 2017) & \\
\hline
\end{tabular}

*MLD = Million litres per day (Source: SPAN, 2017)

Table 3: Domestic Water Use by States in Malaysia in 2014 to 2015

\begin{tabular}{|c|c|c|}
\hline \multirow{3}{*}{ State } & \multicolumn{2}{|c|}{ Water Usage Per Capita (Litre) per Day } \\
\hline & \multicolumn{2}{|c|}{$\mathrm{L} / \mathrm{CAP} / \mathrm{D}$} \\
\hline & 2014 & 2015 \\
\hline Johor & 220 & 211 \\
\hline Kedah & 229 & 223 \\
\hline Kelantan & 147 & 146 \\
\hline Labuan & 170 & 168 \\
\hline Melaka & 234 & 235 \\
\hline N. Sembilan & 223 & 226 \\
\hline Pulau Pinang & 293 & 291 \\
\hline Pahang & 187 & 187 \\
\hline Perak & 239 & 236 \\
\hline Perlis & 258 & 249 \\
\hline Sabah & 114 & 109 \\
\hline Sarawak & 173 & 172 \\
\hline Selangor* & 231 & $234^{*}$ \\
\hline Terengganu & 216 & 214 \\
\hline Malaysia & 211 & 209 \\
\hline
\end{tabular}

*LPD = litres per day (Source: SPAN, 2017)

Table 3 shows that domestic water consumption per capita per day in Selangor recorded a higher rate at 234 litres per capita per day by 2015 .

The water used by individuals in Malaysia and other countries is distinctly different due to several factors, due to different of living standards or the types of activities among consumers. Malaysians cannot disparage the issue of water shortage since year 1998. Water industry players and consumer often blame some factors such as climate, seasonal diversity, environment or other natural factors in dealing with water supply problems whereas various water problems in Malaysia are largely due to human acts [6]. Water resources are scarce due to the destruction of water catchment areas (through logging, land clearing for agriculture, highway and dam construction, etc.), water pollution, wastage of water, free water, low tariffs, lack of incentives for water conservation and public indifference $[7,8]$.

Nowadays in Malaysia, water users are getting water too cheap and easy access lead them to ignore the awareness to appreciate and be grateful for what they have $[9,10]$. For example, in Selangor, although the government has tried to increase water supply with the construction of the Langat 2 Water Treatment Plant, the facility built is unable to solve the water crisis in the Klang Valley. Improvement in physical facilities should be balanced with the mindset by changing attitudes of the consumers on how to save water and conserve the environment. Community involvement to overcome lack of clean water supply has been emphasized by the government as one of the implementation strategies to reduce dependcy on treated water sources and major water sources such as rivers and underground water. This study attempts to understand the attitudes of water users to gain a better understanding on how they apply water-saving practices.

\section{Methodology}

The data was collected from five territorial division located in Gombak District, Selangor, which are Mukim Batu, Mukim Setapak, Mukim Rawang 1, Mukim Rawang 2 and Mukim Hulu Kelang. 400 questionnaires were distributed from December 2016 until January 2017 to residents of Gombak, Selangor using simple random sampling techniques. The total number of questionnaires successfully returned was 397 . Before analyzing the data, the researchers tested the reliability value for all items using Alfa Cronbach test. According to [11], the value of 0.6 and above Alfa Cronbach is applicable. Analytical results of Alfa Cronbach reliability analysis for user attitudes exceeded the score of 0.6. The data was analyzed using SPSS version 21 . The mean score level set [12] was used as a measurement of the attitude level of domestic water users.

\section{Results and Discussion}

Based on the survey results, 180 male and 217 female respondents were involved in the study consisting of Malays (71\%), Chinese (23\%) and Indians (6\%). There were 10 items representing the dimensions of consumer attitudes divided by three main constructs namely cognitive, conative and affective. The Likert Scale (5 points) has been used to evaluate the score from $1=$ Strongly Disagree (DS), $2=$ Disagree (D), $3=$ Not Sure (NS), $4=$ Agree (A) and $5=$ Strongly Agree (SA).

Based on the analysis, Table 4 shows that the total mean value of cognitive attitudes is 4.17 , standard deviation is 0.57 . The scale issued by [12] clearly stated that the respondents' cognitive attitudes in the Gombak, Selangor were at high level compared to other constructs. While the total mean value of conative attitude (behaviour) is 3.27 , standard deviation is 0.77 , and the total mean value of affective attitude is 3.15 , standard deviation is 0.97 , validating the behavioural and affective attitudes of respondents at moderate level.

Hence, cognitive attitudes are at a high level indicating that respondents of this study are more likely to consume water wisely who can significantly reduce the cost of monthly water bills. This is evidenced when $91.7 \%$ of respondents agree and strongly agree with the statement. Based on the information obtained, the source of water is currently depleting, and it is recommended that watersaving practices need to be executed because the knowledge and perceptions that are applied to it are based on consumer's perception.

Table 4: Total mean, standard deviation and user behaviour level according to cognitive, conative and affective constructs

\begin{tabular}{|c|c|c|c|c|}
\hline Item /User Attitude & $\begin{array}{c}\text { Mean } \\
\text { Item }\end{array}$ & $\begin{array}{l}\text { Total } \\
\text { Mean }\end{array}$ & SD & Level \\
\hline Cognitive & & & & \\
\hline $\begin{array}{l}\text { 1. Use water wisely can reduce } \\
\text { the cost of monthly water bill }\end{array}$ & 4.35 & \multirow{4}{*}{4.17} & \multirow{4}{*}{.57} & \multirow{4}{*}{ High } \\
\hline $\begin{array}{l}\text { 2. Water conservation is neces- } \\
\text { sary because of water scarcity }\end{array}$ & 4.17 & & & \\
\hline $\begin{array}{l}\text { 3. It is a challenge to convince } \\
\text { others to conserve water }\end{array}$ & 3.99 & & & \\
\hline $\begin{array}{l}\text { 4. Water saving is my respon- } \\
\text { sibility }\end{array}$ & 4.16 & & & \\
\hline \multicolumn{5}{|l|}{ Conative } \\
\hline $\begin{array}{l}\text { 1. I agree to pay a higher tariff } \\
\text { for a better service }\end{array}$ & 2.86 & \multirow{4}{*}{3.27} & \multirow{4}{*}{.77} & \multirow{4}{*}{ Moderate } \\
\hline $\begin{array}{l}\text { 2. I agree that low water tariff } \\
\text { influence consumer behaviour } \\
\text { towards water wastefulness }\end{array}$ & 3.63 & & & \\
\hline $\begin{array}{l}\text { 3. I agree to pay a higher tariff } \\
\text { for a better water quality }\end{array}$ & 3.15 & & & \\
\hline $\begin{array}{l}\text { 4. The need for water savings } \\
\text { depends on location }\end{array}$ & 3.45 & & & \\
\hline \multicolumn{5}{|l|}{ Affective } \\
\hline $\begin{array}{l}\text { 1. I feel no pressure to con- } \\
\text { serve water at the moment }\end{array}$ & 3.14 & 3.15 & .97 & Moderate \\
\hline
\end{tabular}


2. Water shortage issues don't 2.56 affect me

2.56

Table 5: Percentage of distribution according to cognitive, conative and affective constructs

\begin{tabular}{|c|c|c|c|c|c|}
\hline \multirow[t]{2}{*}{ User Attitude } & \multicolumn{5}{|c|}{$\begin{array}{l}\text { Frequency (Percentage) } \\
\quad(\mathrm{n}=397 ; 100 \%)\end{array}$} \\
\hline & SD & $\mathrm{D}$ & NS & A & SA \\
\hline \multicolumn{6}{|l|}{ Cognitive } \\
\hline $\begin{array}{l}\text { 1. Use water wisely can reduce the cost of } \\
\text { monthly water bill }\end{array}$ & $\begin{array}{c}4 \\
(1)\end{array}$ & $\begin{array}{c}5 \\
(1.3)\end{array}$ & $\begin{array}{c}24 \\
(6.0)\end{array}$ & $\begin{array}{c}181 \\
(45.6)\end{array}$ & $\begin{array}{c}183 \\
(46.1)\end{array}$ \\
\hline $\begin{array}{l}\text { 2. Water conservation is necessary because of } \\
\text { water scarcity }\end{array}$ & $\begin{array}{c}7 \\
(1.8)\end{array}$ & $\begin{array}{c}10 \\
(2.5)\end{array}$ & $\begin{array}{c}35 \\
(8.8)\end{array}$ & $\begin{array}{c}202 \\
(50.9)\end{array}$ & $\begin{array}{c}143 \\
(36.0)\end{array}$ \\
\hline $\begin{array}{l}\text { 3. It is a challenge to convince others to con- } \\
\text { serve water }\end{array}$ & $\begin{array}{c}5 \\
(1.3)\end{array}$ & $\begin{array}{c}19 \\
(4.8)\end{array}$ & $\begin{array}{c}60 \\
(15.1)\end{array}$ & $\begin{array}{c}203 \\
(51.1)\end{array}$ & $\begin{array}{c}110 \\
(27.7)\end{array}$ \\
\hline 4.Water saving is my responsibility & $\begin{array}{c}7 \\
(1.8)\end{array}$ & $\begin{array}{c}13 \\
(3.3)\end{array}$ & $\begin{array}{c}36 \\
(9.1)\end{array}$ & $\begin{array}{c}195 \\
(49.1)\end{array}$ & $\begin{array}{c}146 \\
(36.8)\end{array}$ \\
\hline \multicolumn{6}{|l|}{ Conative } \\
\hline $\begin{array}{l}\text { 1. I agree to pay a higher tariff for a better } \\
\text { service }\end{array}$ & $\begin{array}{c}52 \\
(13.1)\end{array}$ & $\begin{array}{c}133 \\
(33.5)\end{array}$ & $\begin{array}{c}70 \\
(17.6)\end{array}$ & $\begin{array}{c}103 \\
(25.9)\end{array}$ & $\begin{array}{c}39 \\
(9.8)\end{array}$ \\
\hline $\begin{array}{l}\text { 2. I agree that low water tariff influence con- } \\
\text { sumer behaviour towards water wastefulness }\end{array}$ & $\begin{array}{c}11 \\
(2.8) \\
\end{array}$ & $\begin{array}{c}57 \\
(14.4) \\
\end{array}$ & $\begin{array}{c}78 \\
(19.6) \\
\end{array}$ & $\begin{array}{c}172 \\
(43.3) \\
\end{array}$ & $\begin{array}{c}79 \\
(19.9) \\
\end{array}$ \\
\hline $\begin{array}{l}\text { 3. I agree to pay a higher tariff for a better } \\
\text { water quality }\end{array}$ & $\begin{array}{r}38 \\
(9.6) \\
\end{array}$ & $\begin{array}{c}103 \\
(25.9)\end{array}$ & $\begin{array}{c}71 \\
(17.9) \\
\end{array}$ & $\begin{array}{c}133 \\
(33.5)\end{array}$ & $\begin{array}{c}52 \\
(13.1) \\
\end{array}$ \\
\hline $\begin{array}{l}\text { 4. The need for water savings depends on } \\
\text { location }\end{array}$ & $\begin{array}{c}21 \\
(5.3)\end{array}$ & $\begin{array}{c}63 \\
(15.9)\end{array}$ & $\begin{array}{c}87 \\
(21.9)\end{array}$ & $\begin{array}{c}167 \\
(42.1)\end{array}$ & $\begin{array}{c}59 \\
(14.9)\end{array}$ \\
\hline \multicolumn{6}{|l|}{ Affective } \\
\hline $\begin{array}{l}\text { 1. I feel no pressure to conserve water at the } \\
\text { moment }\end{array}$ & $\begin{array}{r}26 \\
(6.5) \\
\end{array}$ & $\begin{array}{c}113 \\
(28.5)\end{array}$ & $\begin{array}{c}76 \\
(19.1) \\
\end{array}$ & $\begin{array}{c}142 \\
(35.8)\end{array}$ & $\begin{array}{c}40 \\
(10.1) \\
\end{array}$ \\
\hline 2. Water shortage issues don't affect me & $\begin{array}{c}81 \\
(20.4)\end{array}$ & $\begin{array}{c}149 \\
(37.5)\end{array}$ & $\begin{array}{c}59 \\
(14.9)\end{array}$ & $\begin{array}{c}80 \\
(20.2)\end{array}$ & $\begin{array}{c}28 \\
(7.1) \\
\end{array}$ \\
\hline
\end{tabular}

In other words, the users hold the acceptance that the object of her or his attitude has a certain attribute and that particular behaviour will bring a positive result [13]. Hence, the cognitive attitudes state by [14] and [15] prove that knowledge, beliefs and judgment of a person on an object or situation can change the user's behaviour.

Referring to [16], they argue that affective components involve feelings and emotions of an object. The affective attitude of the respondents of this study was at a moderate level with the lowest overall mean score of 3.15 , indicating that feelings or emotions covered the respondents' anxiety over water shortage issues occurring in Gombak, Selangor. While a total of 108 people or 27.3 per cent chose to agree with water shortage, which does not affect them, may be expressively and emotionally formed without accurate information about water supply issues in Selangor.

Nearly half of the respondents, 182 or $45.9 \%$, felt that there was no pressure for them to save water at this time. In their opinion, this respondent's view is caused by the perception of respondents who opine the water resources in Malaysia are abundant. According to [17], Malaysia will experience El Nino phenomenon more often in every two years over the next few years due to global warming caused by various factors such as urban development, the release of carbon dioxide gas by increased use of vehicles as well greenhouse effect. Coincide with Earth Day in 2017 with the theme 'Environmental and Climate Education', the community should be educated to be more sensitive or concerned about environmental crisis, especially lack of clean water sources in the country.

In addition, the study also found that 185 or $46.6 \%$ of respondents refused to pay higher tariffs for better services. While over half of the respondents, 251 people or $63.2 \%$ agreed that low water tariffs affected consumers' behaviour on water wastage. The outcome is in line with [18] which found that low water tariffs affected the level of water saving practices. Among the positive effects found in this study were the conative attitudes of encouraging consumers to contemplate and maintain positive behaviour regarding water tariffs - that almost half of the total respondents, 185 or $46.6 \%$ agreed to pay higher tariffs for better water quality.

The study highlights the importance of consumer's attitudes to act on certain behaviours based on individual's desire and to do deeds according to their convictions and aspirations [13-15]. Respondents also responded positively to the willingness to pay more when it involved the importance of water quality. Conative atti- tude of respondents, as described by [16] was the result of cognitive and affective components to a person on an option to act on things and vice versa.

\section{Conclusion}

In general, users' attitudes examined by the three constructs were found at high level, which indicate that respondents are very responsive to conserve water, reduce water wastage and subsequently reduce utility bills among households in the study area. Sustainability of resources and environmental impacts are issues to be addressed by the government to achieve the status of developed nation. There are various approaches, including environmentalfriendly practices (MASMA-JPS) or Green Practices (GP) introduced by the industry players to resolve this global issue [19]. GP approach usually starts with efforts to raise awareness, and followed by action and implementation.

\section{Acknowledgement}

The authors would like to thank the Research Management, Innova-tion and Commercialization Centre, Universiti Sultan Zainal Abidin, Terengganu, Malaysia for providing the financial assistance to support the publication fee of this article.

\section{References}

[1] Cherian, J.T. (2009). Water demand management in Selangor - why and how? http://www.crbom.org/public/1534991275-SPS07Selangor-0.pdf.

[2] Renganathan, M. (2000). Taking care of water, the responsibility of all. Proceedings of the National Seminar Environmental Management Plan for the Proposed Beris Dam Project in Kedah Darul Aman.

[3] Suruhanjaya Perkhidmatan Air Negara (SPAN). (2017). Data dan statistik penggunaan air http://www.span.gov.my/index.php?option=com_content\&view=art icle\&id=533\&Itemid=420\&ang=en\#.

[4] Mygreentech. (2011). Universiti Utara Malaysia - Go for Green Building untuk jimatkan air. //mygreentech.blogspot.com/2011/04/universiti-utara-malaysia-gofor-green.html. 
[5] Suruhanjaya Perkhidmatan Air Negara (SPAN). (2016). Kaji selidik berhubung dengan kepuasan pengguna domestik dan komersial dan industri terhadap kualiti penyampaian dan pengagihan perkhidmatan air oleh Merdeka Centre. Bulletin SPAN, Bil 4 Oktober-Disember 2016.

[6] Chan, N.W. (2009). Issues and challenges in water governance in Malaysia. Iran Journal of Environment, Health and Science, 6(3), 143-152.

[7] Ahmad, Z.S. (2013). Urus air seperti urus nyawa sendiri. Utusan Melayu (M) Bhd. http://www.utusan.com.my/rencana/utama/urusair-seperti-urus-nyawa-sendiri-1.462790\#ixzz4x3SYdQNZ

[8] Chan, N.W. (2005). Sustainable management of rivers in Malaysia: Involving all stakeholders. International Journal of River Basin Management, 3(3), 147-162.

[9] Chan N.W. (2012). The N-Park Negalitres Project: A pilot watersaving initiative using green technology and changing water use behaviour.

https://www.uncclearn.org/sites/default/files/inventory/unu11.pdf\# page $=93$.

[10] Tuan, P.R., Hamidi, I., \& Wahida, A. (2004). Sikap masyarakat terhadap penggunaan bekalan air bersih: Pembaziran dan Penjimatan. Universiti Utara Malaysia.

[11] Pallant, J. (2011). A step by step guide to data analysis using SPSS. Allen and Unwin.

[12] Woo, S.F. (2008), Faktor-faktor yang mendorong tekanan kerja (stres) di kalangan guru-guru SJK(C): Satu kajian di tiga buah sekolah di Wilayah Persekutuan. PhD thesis, Universiti Teknologi Malaysia.

[13] Schiffman, L.G., \& Kanuk, LL. (1996). Consumer behaviour. Prentice Hall.

[14] Daramdeo, S. (2006). Consumer behaviour with respect to domestic water in mauritius including a model. $\mathrm{PhD}$ thesis, University of South Africa.

[15] Carmichael, B.A. (2006). Linking quality tourism experience, residents' quality of life, and quality experience for tourist. In G. Jennings, \& N. P. Nickersons (Eds.), Quality Tourism Experience. United Kingdom: Elsevier - Heinemann, pp. 115-135.

[16] Cant, M., Brink, A., \& Brijbali, A. (2002). Consumer behaviour: A South African perspective. Juta.

[17] Nurul, N.A.T. (2016). Malaysia akan kerap alami fenomena EL Nino - Pakar. http://www.utusan.com.my/sains-teknologi/alamsekitar/malaysia-akan-kerap-alami-fenomena-el-nino-pakar1.304789 .

[18] Chan, N.W. (2008). Water watch Penang: Using water demand management (WDM) for water sustainability via changing lifestyle and water use habits. Water Watch Penang.

[19] Jabatan Bekalan Air (JBA). (2017). Kementerian Tenaga, Teknologi Hijau dan Air Malaysia. http://www.jba.gov.my/index.php/soalan-lazim-baru. 